\title{
RESISTING DEHUMANIZATION:
}

\section{ACTS OF RELATIONAL CARE IN EXODUS 1-2 AS IMAGE OF GOD'S LIBERATING PRESENCE}

\author{
Juliana M Claassens \\ Old and New Testament \\ Stellenbosch University
}

\begin{abstract}
In her provocative book, The Female Face of God in Auschwitz: A Jewish Feminist Theology of the Holocaust (2003), Melissa Raphael argues that the exceedingly ordinary acts of women washing or caring for their own bodies or the bodies of others reflected something of the liberating presence of God in Auschwitz. These 'simple acts of humanity' had the purpose of restoring the personhood that was seriously imperiled by the dehumanizing acts of the Nazis in the death camps. Raphael's constructive theological construction that uses the lives of ordinary women to image God's liberating presence in Auschwitz will be used as hermeneutical lens in rereading the stories of the five women in Exodus 1-2, whose acts of relational care for the baby Moses serve the function of resisting the dehumanization underlying the acts of genocide reflected in this text. Moreover, the decision of these women to protect the vulnerable and to preserve life precedes or foreshadows God's liberation, so serving as an image of God's liberating presence.
\end{abstract}

Key Words: Human Dignity, Feminist Biblical Interpretation, Exodus, Holocaust

\section{Introduction}

In her recent book, Plantations and Death Camps: Religion, Ideology and Human Dignity that investigates the dehumanization experienced by the African American slaves on the slave ships and on the plantations in the Southern part of the United States, as well as by the millions of Jews who during the time of the Shoah were forcefully removed to death camps, starved to death and kept in the most vile, unsanitary conditions imaginable, Beverly Mitchell (2009:26-29) argues that it is in the worst 'hovels of human existence' where one truly sees what it means to be human. The reason for this is that a common feature of these disparate situations of dehumanization is that to be human ultimately means to resist those forces that seek to assault, violate or obscure one's human dignity.

When one turns to biblical traditions, few texts speak of dehumanization as distinctly as the story told in Exodus 1-2 of Israel's experience of slavery in the land of Egypt. Exodus 1-2 attests of what Mitchell (2009:57) calls the 'sin of defacement,' i.e. the tendency by the perpetrators to make other people invisible or inconsequential or less than human. This is evident in the reference in Exod 1:7 that 'Israelites swarmed' (שרץ) - one could say in harsh terms 'procreated like bunnies' - as well as the reference to the midwives playing on Pharaoh's racial stereotypes when they state in $\mathrm{v} 19$ that the Israelite women are like animals; when the midwives get there, the babies are already born. ${ }^{1}$

Renita Weems argues that the racial differences and stereotypes assumed by this story are not challenged by the characters and/or the narrator. Rather the story simply inverts these stereotypes in order to serve its own 
But even more so, in Exodus 1 we see how the Pharaoh's attempt to stem the population growth of these undesirables results in his decision that these less than human beings are not fit to live. As evident in Nancy Lee's essay, “Genocide's Lament: Moses, Pharaoh's Daughter, and the Former Yugoslavia" (1998), the malicious murder of the babies of the Israelites calls to mind other experiences of genocide - what in at least one instance would be called the 'Final Solution.'

And yet, as we will see in the first part of this paper, amidst the depths of degradation reflected in Exodus 1-2, one finds evidence of how human dignity is preserved in the way five women responded to these acts that violated the sanctity of human life. The relational care exercised by the midwives Shiprah and Puah, Moses' mother and sister, and the daughter of the Egyptian Pharaoh, in protecting the lives of the community's most vulnerable members, serves the function of resisting the actions of a cruel empire set on destroying life.

In the second part of this paper, we will consider how these acts of relational care as means of resisting dehumanization serve as an image of God's liberating presence exactly there where people's humanity is most threatened. In conversation with the work of Melissa Raphael (2003), who argues in her book The Female Face of God in Auschwitz that the exceedingly ordinary acts of women washing or caring for their own bodies, or the bodies of others, reflected something of the liberating presence of God in Auschwitz, I propose that the courageous actions of the five women in Exodus 1-2 protecting the vulnerable and preserving life precede or foreshadow God's liberation.

Finally, this paper will consider the importance of cultivating biblical reading practices such as illustrated in this paper as a way to encourage people in South Africa who have seen, and in too many instances still see, its share of dehumanizing events, to embrace ways to resist dehumanization.

\section{Being Human}

In considering the human response to dehumanization it is worth noting that the very fact that testimony is preserved in response to instances where people's human dignity is threatened already serves as a sign of resistance. In this regard, Beverly Mitchell (2009: 32-33) notes that a basic human need of those who suffer unjustly is to bear witness. To tell one's story ultimately is a sign of strength and an attempt to maintain one's dignity in the face of degradation.

It is thus not surprising that when writers such as Beverley Mitchell and Melissa Raphael write on the question of human dignity with reference to the most demeaning of circumstances, they turn to first person accounts such as memoirs, journals and diaries with the purpose of allowing subjects who have been silenced - the ultimate form of dehumanization - to speak once more. By listening to the testimony of what victims had to endure, and in serving as witness to the ways, no matter how small or seemingly insignificant, in which these victims resisted their perpetrators' most valiant attempts to humiliate, destroy and annihilate their humanity, human dignity manifests itself once more (Mitchell 2009:4).

ideological interests. Weems ends her essay with the question whether one can use this story for liberation, answering as follows: "Not without due caution," "The Hebrew Women Are Not Like the Egyptian Women: The Ideology of Race, Gender and Sexual Reproduction in Exodus 1," In Ideological Criticism of Biblical Texts, (eds.) David Jobling and Tina Pippin; Semeia 59 (1992):32-33. 
A common theme in women's memoirs that recount life in Auschwitz relates to the abhorrent conditions in which victims had to live that in itself became an assault on their personhood. For instance, Melissa Raphael (2003:81) describes 'the gross indignities of bodily degradation;' the diarrhea due to typhus and other ailments; the lack of opportunities and facilities to wash oneself that existed in the extermination camps. ${ }^{2}$

Yet once more, being human ultimately means to resist dehumanization in whatever (limited) way possible. Raphael argues that the exceedingly ordinary acts of women washing or caring for their own bodies or the bodies of others, which she calls 'simple acts of humanity,' had the purpose of restoring the personhood that was seriously imperiled by the dehumanizing acts of the Nazis in the death camps. By washing, these women engaged in an active resistance against the humiliation and degradation they experienced at the hands of the Nazi's. ${ }^{3}$ In this regard, Raphael (2003:69) recalls a poignant recollection by Olga Lengyel (1995:123):

No spectacle was more comforting than that provided by the women when they undertook to cleanse themselves thoroughly in the evening. They passed the single scrubbing brush to one another with a firm determination to resist dirt and the lice. That was our only way of waging war against the parasites, against our jailers, and against every force that made us its victims.

One also sees this active resistance against the degradation of those seeking to violate their human dignity in other acts of relational care in the death camps. Raphael (2003:10) uses the nurturing and protective actions of mothers rooted in "a capacity to bend over and cover, stroke, warm, feed, clean, lift and hold the other," to depict "an embodied resistance to Auschwitz which had institutionalized the exposure, breakage and waste of bodies." She argues that in Auschwitz "mothers had mothered daughters; daughters, mothers; sisters, sisters; friends, friends; and mothers, other mothers." ${ }^{4}$ For instance, Raphael (2003:112) recounts the story told by Sara Nomberg-Przytyk who in 1945 during the long march from Auschwitz before the approaching Russian army was close to death from exposure, when a nameless woman from the next wagon gave her own camp blanket to Sara saying that she would share with her daughter. When Sara repeatedly asked for her name, the woman told her to stretch out her hand. As she complied, the unknown woman placed a dry crust of bread in her hand.

These instances of random acts of kindness across biological and familial ties not only are indicative of desperately clinging to one's own humanity but also of preserving the human dignity of others who were in even worse shape than themselves. And ultimately these acts of relational care for the self and for others that constitute a cry of protest against

2 These acts of female care formed for Raphael (2003:83) "a kind of mishkan [Tent of Meeting] in the holocaust desert of blood, mud and excrement." Cf. also Mitchell's description of the "assault of excrement" in both the extermination camps, as well as on the slave ships on the human dignity of their Jewish and African American victims (2009:26-29).

3 Reminiscent of Jewish women's actions of washing themselves and objects in preparation for the Sabbath, Raphael (2003:76) argues as follows: "God is to be found wherever places are made holy by acts and intentions and wherever we conduct ourselves as to invite God's presence among us."

4. Raphael (2003:96-97) notes that virtually all women in Auschwitz formed surrogate families: women adopting children; children adopting mothers - these friendships and quasi-familial relationships playing a key role in the effort to survive. 
the perpetrators' assault, serve as Mitchell (2009:43) argues as a "staunch testimony to the ultimate indestructibility of human dignity."

When it comes to the account of slavery and genocide in Exodus 1-2, it is remarkable that the actions of five women resisting the dehumanizing actions of the Pharaoh are preserved in these foundational narratives. By including the memory of these women in the larger story of liberation, and by focusing on these women's actions, we today are able to tell the story differently, expanding and reconceptualizing the traditional story line to include women as subjects of history. ${ }^{6}$

When we consider the response of the women to the dehumanization underlying the acts of genocide reflected in Exodus 1-2, it becomes evident that this response entails multiple acts of relational care, what Jacqueline Lapsley (2005:85) calls "a cooperative network of care and nurture of those most vulnerable to violence." We see this in the actions of the midwives who at great personal risk overtly disobey the Pharaoh in order to save the Israelite babies. Employing double-voiced speech, ${ }^{7}$ the midwives outwit the Pharaoh when they draw upon his stereotypes of Hebrew women (they are like animals), so covering up the real reason behind the midwives' refusal to kill the male babies of the Israelites (Lee 1998:81; Exum 1983:60). Exod Rabbah 1:15 offers an imaginative interpretation that helps us to imagine the motivation underlying these midwives' actions. Modeling themselves upon Abraham who was even willing to sacrifice his son, the midwives contemplate as follow:

Abraham, out of loving kindness, fed all passersby, regardless of their faith, and we are not only unable to provide the babies with food, but we've been ordered to murder them! No. We will keep them alive in any way we can (Quoted in Ronson 1998:192).

The decision of the midwives to resist the Pharaoh's decree to destroy human life is rooted in the nature of the midwife's profession that intrinsically is connected to bringing life into the world. In this regard, one should bear in mind the close association that exists between the soon-to-be mother and the midwife which may be responsible for the commitment to protect the life of another human being. In her study on the relationship between gender and healing in the ancient world, Elaine Wainwright argues that "at the centre of this female space occupied by midwife and pregnant woman are the bodies of women. Bodies touch as the hands of the midwife enable the birth process in and from the body of the other woman." Drawing on the work of Elizabeth Grosz whose work on touch reminds us that

5 Mitchell (2009:43) argues for the indestructibility of human dignity in light of the fact that human dignity is a God-given gift bestowed by the Creator-God upon all humans regardless of their abilities, capabilities or disabilities, physical and mental."

6 And as Elizabeth Johnson (1999:161) notes, in this process, we are making room for real women to exist as subjects in their own right. However, one should note that the memories of these women are vulnerable; they easily disappear in the midst of the power struggles of the powers-that-be. Eileen Schuller (1989:182-185) makes a compelling argument that any reference to the stories of the midwives disappeared in the postbiblical literature that revised the foundational stories of God's liberation. For instance, in the book of Jubiliees' retelling of the Exodus story, the midwives vanish completely [cf. also Biblical Antiquities (Pseudo-Philo) in which local chiefs are said to have replaced the midwives] (Langston 2006:17-21). Cf. also Cheryl Exum's argument who in her reconsideration of her seminal essay, "“You Shall Let Every Daughter Live,"” proposes that she now is of the opinion that the positive portrayal of the women in this text only is there to serve male interests, i.e., women working together to save the male saviour then disappearing from the scene (2000:7584).

7 Cf. Lapsley's argument that the midwives' speech can be read on two levels. On the one hand their assertion that the women are like animals plays on the Pharaoh's stereotypes that the Hebrews are less than humans, on the other hand their statement may actually be read as praise for the women's ability to thrive under difficult circumstances (2005:71). 
'the toucher is always touched,' Wainwright (2006:40-41) considers the imaginative possibilities embedded in this 'female space of childbirth' - particularly with reference to the incredible 'power of touch' - something that may be in particular important when it comes to recognizing the common humanity of the person whom one is facing.

It is further significant that the midwives in this story of liberation do not labour alone. Jochabed (Moses' mother), Pharaoh's daughter, and Miriam (Moses' sister) all continue the work started by the midwives, consistently making choices for life and not death. In their respective ways, these women serve as mothers and surrogate mothers to the baby Moses, united by the overall objective of preserving life.

So Moses' mother resists the Pharaoh's horrific decree by devising a plan of how she can keep her baby safe. She gets a wicker basket, and after making sure her child is sheltered well from the cold by plastering it with waterproof material, she places the child in the basket and hides him in the reeds by the river (Exod 2:3). Moses' sister takes over where her mother left off, taking the task of watching over the baby upon herself as she watches from a distance (v. 4), in the process serving as a protective presence. And when the Egyptian princess hears the baby crying and instructs her servants to bring the baby to her, Moses' sister dares to approach the daughter of the very engineer of the genocide. The young girl's ingenuity allows for the baby to be nursed by his own mother - her acts of relational care thus extending to ensuring nourishment and comfort of this vulnerable child in need of care.

Within this collaborative effort of caring for this child, the action of the Pharaoh's daughter is significant. Actually her action of pulling the baby from a certain watery grave (or at least one of her servants) can be construed as emulating the action of the midwife drawing the baby from the womb. This action is reflected in the name that the Egyptian princess bestows on the baby in Exod 2:10 - the Hebrew meaning of the root 'to draw up' (מש] infusing the typical Egyptian name (Moses) with ironic significance. ${ }^{8}$ Moreover, the acts of the Princess (and her servants) of pulling the baby out of the water, conceivably cleaning and comforting the crying infant, become an example of relational care across biological as well as racial lines. ${ }^{9}$ The princess' actions are representative of the ability to discern a common connection between humans that transcends racial, ethnic, biological and national categories. Her decision to save a Hebrew baby is grounded in compassion, being able to see the baby as a subject as evident in Exod 2:6 where it is said that the princess heard the baby's cry, and she was compassionate (חמל) unto him. This ability to hear and see and respond to another's pain is a sign of being able to recognize a common vulnerability that is essential in discovering a common humanity. It means that one is able to recognize, as Mitchell (2009:46) suggests, the social dimension of human dignity, i.e., 'that our humanness is tied to that of every other human being,' and even more

8 The proper name Moses generally takes to be Egyptian compared to e.g., Thutmoses, Ahmoses, and Ramoses. However, as noted above, the princess explains the name in terms of Hebrew etymology. It is important though to note as Exum (1983:56-57) points out that the pointing of the name Moses would actually follow the Qal Active Participle pattern that would instead of a verb "I drew out" rather be read as "the one who draws out," hence alluding to Moses' future role as deliverer.

9 Cf. also that fact that the identity of the midwives is ambiguous in nature - they are either Hebrew midwives or midwives to the Hebrews that may suggest that they are Egyptian. If one were to choose for the latter reading, the theme of crossing ethnic boundaries that forms a key theme in this text is even stronger. The Masoretes who added vowels to the text considered them to be "Hebrew midwives;" however, this does not solve the ambiguity in the text (Lapsley 2005:72). Whether Egyptian or Hebrew it is clear that these women midwives refuse to comply with the Pharaoh's plan of using the women as Eileen Schuller (1989:179) suggests, "agents of death rather than life." 
so, "that our humanity is completed in the presence of others who also know our value and worth." When one recognizes this awareness of a shared humanity, one would be more inclined to acknowledge one's responsibility towards the other, recognizing that we are as Mitchell (2009:49) calls it 'keepers of each other.'

\section{God's Liberating Presence}

This response by people in the face of whatever seeks to diminish or destroy human dignity offers us the opportunity to consider the larger and exceedingly difficult question with regard to God's presence in terrible situations of dehumanization such as in Auschwitz or in the context of slavery or one could say Apartheid.

In her book, The Female Face of God in Auschwitz, Melissa Raphael critiques fellow post-Holocaust thinkers who have caused God to 'disappear' from holocaust space and time. Scholars such as Emmanuel Levinas, Martin Buber and Eliezer Berkovits have all argued for some form of God's hiddenness to explain God's silence or non-involvement in the Holocaust. ${ }^{10}$ Yet, as Raphael (2003:47) argues, citing the example of the mother of two 10-year old twin girls Nellie and Vlodka Blit, who managed to house her daughters with a Gentile family in Warsaw, who would walk daily by their house so that the two girls could see her from their window: "Presence, a keeping watch, is a function of love. A present God paces back and forth, circling the object of her concern; an absent God seems to have walked away."

It is for this reason that Raphael seeks to reimagine God's relationship to the Jews during the Holocaust. She seeks God's presence in the stories of ordinary women who through such commonplace acts of washing or caring for their own bodies or the bodies of others, as well as other relational acts of caring for one another reflected something of the liberating presence of God in Auschwitz. By focusing on these acts of relational care as brought under our attention by the memoirs of women writing about their experience in Auschwitz, Raphael (2003:88) moves toward a theology of presence as she argues that it is in the cleansed face of the other that one sees the female face of God. As she says: "God is present wherever personhood is honoured."

It is in the numerous examples of women who "showed compassion to those even more broken than themselves that God's presence was revealed in Auschwitz. Raphael writes that these acts of kindness were in many senses futile and pitifully ineffectual to the scale of loss, terror, and deprivation." But as Raphael (2003:10) argues, in none of the memoirs she had read for the purpose of her study "was their comforts incidental or peripheral to meaning and hope, then or now."

Read through this lens, one can ask similar questions with regard to God's presence in Exodus 1-2 where not only the life of babies but the whole of Israel is jeopardized. Actually

10 Cf. e.g., Berkovits 1973; Buber 1953; Levinas 1999.

11 This constructive theological construction that uses the lives of ordinary women to image God's "feeding, clothing, and saving presence" in Auschwitz, so validating women's experience and retrieving the memorie of women surviving (and not surviving) amidst very difficult circumstances, aligns with the Jewish tradition that depicted the female presence of God in terms of the Shekhinah who is said to have gone with Israel into exile, and who suffers with her people. As Megillah 29a states: "Come and see how beloved Israel is before God; for whenever they went into exile the Shekhinah went with them. When they were exiled to Egypt, the Shekhinah went with them, in Babylon the Shekhinah was with them, and in the future, when Israel will be redeemed, the Shekhinah will be with them." According to rabbinic tradition, this divine presence in the form of the Shekhinah extends to times when Israel is unclean (Yomah 56b), watching over them when they are sick (Shabbat 12b) and hurting when they are in pain (Sanhedrin 46a) (Raphael 2003:82, 128). 
it is noteworthy that God is hardly present in the whole of this distressing narrative - it is only in Exod 2:23-25 where it is said that God heard their cries, saw their misery and knew what they had gone through. And yet, long before God is said to hear, see, and know, we find how the women in this story, very much ordinary people with limited power and influence, see the misery, hear the cries and know about the suffering of their children (and in the case of the Egyptian princess, the children of 'others').

In light of Raphael's proposal that God is present wherever human dignity is respected, one can argue that in Exodus 1-2 one encounters in these acts of relational care by the hands of the midwives, Moses' mother and sister, as well as the Egyptian princess and her servants, that sought to protect the vulnerable and to preserve life, something of God's presence. One can say that the response of the women to the dehumanizing acts of the Pharaoh and his agents by means of caring, keeping safe, feeding, watching over, cleaning, and consoling precede or foreshadow God's liberation, so serving as an image of God's liberating presence. These courageous boundary-crossing actions of the female characters intent on preserving life eventually become the governing divine values, pointing to the liberation of all people from the social, cultural and political boundaries that confine humans (Lapsley 2005:87).

To re-imagine God's liberative action in Exodus 1-2 in terms of the acts of relational care of its female characters has the following implications. First, invoking the metaphor of God's liberating presence as embodied in the actions of ordinary women caring and comforting and protecting those in need, has a significant effect on how we think about God as Liberator. For instance, as the midwives and the other women worked ceaselessly to bring life into the world, often in trying and treacherous circumstances, an image of a Liberator God emerges that is profoundly committed to life, hearing the cries of those who are violated and working by means of ordinary human beings to resist violence and restore human dignity. This portrayal offers an important counterpoint to the dominant portrayal of God's liberation in terms of the Mighty Warrior who through his arsenal of sea and wind slays the Egyptian soldiers at the seashore (Exod 14-15); and before that, using all kinds of plagues to attack the Egyptians' property, eventually smiting their firstborn (Exod 7-12). According to Nancy Lee (1998:76-77) such a portrayal of God as destroyer of life does not comply with the work of the midwives and the Egyptian princess who in Exodus 1-2 saved babies even across biological and ethnic boundaries. She argues as follows: "God is neither able nor willing in the end to show mercy and cross this boundary to secure the safety of Egyptian as well as Hebrew children," but rather resorting "to the same practice, the killing of children, that Pharaoh uses in his abuse of power." Yet, to highlight God's liberating presence in terms of the relational care offered by the midwives and the other women in Exodus 1-2 offers us, the readers, the opportunity to counter or resist the violent portrayal of God in terms of the understanding that God is a God of life, who will work ceaselessly to bring life into the world.

Second, to reimagine God as Liberator in terms of God's liberative presence as embodied in the acts of relational care of ordinary people, may in turn shape people's ongoing quest to resist dehumanization. As Raphael (2003:57) argues: "God can only do her restorative work in and with those who care" who 'labours alongside her.' This understanding is also at the heart of Sharon Welch's ethic of solidarity according to which she proposes that people are "empowered by a recognition of the power of divine love and healing at work in our communities of resistance." She argues: "Our efforts are partial, yet they are divine in their love and courage. They bear witness to the transcendent, healing power of love; they bear witness to the beauty and wonder of life" (1990:180). Even though 
this work may be limited, fragmented and in some instances even seemingly futile, these acts of care and kindness are at the core of what it means to be human (Welch 1990:173, 178).

\section{Conclusion: Liberating Reading Practices}

A final word regards the necessity of cultivating liberating reading practices. In terms of all the situations where acts of violence and dehumanization have become commonplace, as well as those instances in which the dehumanization is much more subtle, yet no less distressing, one sees that there exists a certain logic - a logic of racism, sexism, homophobia that in its worst and most extreme form results in genocide or hate crimes or modern day witch-hunts. In order to resist these forms of dehumanization, it is necessary to identify this logic, and then to interrupt this logic by showing its limitations or by offering an alternative world based on a shared sense of humanity. With reference to our reading of Exodus 1-2, we saw how within the context of the genocide and maltreatment, the presence of the women caring, comforting, and protecting across ethnic lines, which speaks of a deep respect for their common humanity, interrupts the logic of the Pharaoh who is intent on wiping off the face of the earth those whom he consider less-than-human.

In similar vein, we today are called to interrupt those instances where the least and the last of these in the world around us are overlooked, diminished, and regarded as less than human. A good place to start is by cultivating liberating reading practices such as noticing the minor voices in the biblical text - the reason being that the way one reads also says a lot about the way one lives. By telling the stories of those women such as the midwives, mothers, sisters in Exodus 1-2, as well as women throughout the ages who serve as embodiment of God's presence, people may learn to think not only differently about God, but also to regard those who have been forgotten or overlooked in their own communities in a new way. For instance, by highlighting the stories of the female characters that hide somewhere in the midst of the broader story, allowing their muted voices to speak over the microphone to our congregations, we also may start noticing the women in our congregation and in our communities: those named and those who are anonymous, the mothers, wives, daughters, grandmothers, teachers, nannies, cleaning ladies, cashiers, prostitutes, homeless bag ladies who can be described as Elizabeth Johnson (1999:157) so poetically expresses:

These are women of every tongue and culture who bore and birthed, farmed and harvested, fetched and fed, cleaned and mended, taught and protected little ones, related to husbands, poured forth endless labor, pondered and prayed, sought their own space and exercised their wits in a patriarchal world, finding their connections to the sacred in the midst of myriad daily sufferings and joys. Their circle is as wide as the earth, including women from our own family trees and women of different races, classes, and ethnic cultures; women from the recent past and women long distant in time; struggling, poor, artistic, prophetic, quiet, shouting, funny, loving, suffering, self-defining, seeking, defiant, scared, subtle, sexy, gutsy women of all ages.

Moreover, liberating reading practices imply that by focusing on the courageous acts of resistance of ordinary women, who in small and often seemingly insignificant ways resisted whatever individuals and forces sought to make themselves and others around them less than fully human, one contributes to the formation of a more just and humane world in which it is not acceptable to diminish or degrade the worth of women, men and children, regardless of race or sexual orientation in any way whatsoever. Within this world, an ethos reigns where life-affirming, dignity-respecting actions are celebrated and considered the 
norm - an ethos that in turn impacts the way we think; the way we speak; and the way we act. Encouraged by God's liberating presence, as embodied in the actions of ordinary human beings seeking to resist dehumanization, we may work individually and collectively to bring such a world into being.

\section{BIBLIOGRAPHY}

Berkovits, Eliezer 1973. Faith After the Holocaust. New York: KTAV.

Buber, Martin 1953. The Eclipse of God: Studies in the Relation Between Religion and Philosophy. London: Gollancz.

Exum, J Cheryl 1983. 'You Shall Let Every Daughter Live': A Study of Exodus 1.8-2.10.” Semeia 28:63-82.

--- 2000. "Second Thoughts about Secondary Characters: Women in Exodus 1:8-2:10." Pages 75-84 in Brenner, Athalya (ed.). A Feminist Companion to Exodus to Deuteronomy. Sheffuield: Sheffield Academic Press.

Johnson, Elizabeth A 1999. Friends of God and Prophets: A Feminist Theological Reading of the Communion of Saints. Sheffield: Continuum.

Langston, Scott M 2006. Exodus Through the Centuries. Oxford: Blackwell Publishing.

Lapsley, Jacqueline E 2005. Whispering the Word: Hearing Women's Stories in the Old Testament. Louisville, Kentucky: Westminster John Knox Press.

Lee, Nancy E 1998. “Genocide's Lament: Moses, Pharaoh's Daughter, and the Former Yugoslavia." Pages 66-82 in Linafelt, Tod and Beal, Timothy K (eds.). God in the Fray: A Tribute to Walter Brueggemann. Minneapolis, MN: Fortress.

Lengyel, Olga 1995. Five Chimneys. New York: Howard Fertig.

Levinas, Emmanuel 1999. "Loving the Torah More than God." Pages 79-87 in Kolitz, Zvi. Yosl Rakover Talks to God. Translated by Carol Brown Janeway. New York: Pantheon Books.

Mitchell, Beverly Eileen 2009. Plantations and Death Camps: Religion, Ideology, and Human Dignity. Minneapolis, MN: Fortress.

Raphael, Melissa. 2003. The Female Face of God in Auschwitz: A Jewish Feminist Theology of the Holocaust. Religion and Gender. London: Routledge.

Ronson, Barbara L Thaw 1998. The Women of the Torah. Northvale, NJ: Jason Aronson Inc.

Schuller, Eileen 1989. "Women of the Exodus in the Biblical Retellings of the Second Temple Period." Pages 178-194 in Gender and Difference in Ancient Israel. Edited by Peggy L Day; Minneapolis, MN: Fortress.

Wainwright, Elaine 2006. Women Healing/Healing Women: The Genderization of Healing in Early Christianity. London: Equinox

Weems, Renita J 1992. "The Hebrew Women Are Not Like the Egyptian Women: The Ideology of Race, Gender and Sexual Reproduction in Exodus 1." Semeia 59:25-34.

Welch, Sharon 1990. A Feminist Ethic of Risk. Minneapolis, MN: Fortress. 